\title{
Pemodelan dan Simulasi Pedestrian Untuk Evakuasi Bencana pada Kawasan Boulevard Manado Menggunakan Model Cellular Automata
}

\author{
William Dave Wenno, Steven R. Sentinuwo, Alwin M. Sambul \\ Teknik Informatika Universitas Sam Ratulangi Manado, Indonesia. \\ williamwenno@gmail.com, steven@unsrat.ac.id, asambul@unsrat.ac.id
}

\begin{abstract}
Abstrak - Melakukan evakuasi bencana pada kawasan Boulevard memerlukan penanganan yang tepat. Kawasan Boulevard merupakan salah satu kawasan unggulan di kota Manado. Menjadi pusat perbelanjaan dan hiburan di kota Manado, membuat kawasan ini cukup padat pengunjung. Hasil dari penelitian ini adalah sebuah model dan perangkat lunak aplikasi simulasi proses evakuasi pedestrian pada kondisi bencana tsunami yang berpotensi terjadi dengan menggunakan model Cellular Automata. Cellular Automata merupakan permodelan matematika dari suatu sistem fisis dimana ruang dan waktu tersebut dijadikan diskrit. Dan kuantitas fisinya terdiri dari himpunan berhingga nilai-nilai diskrit. Simulasi berjalan sesuai dengan jumlah inputan pejalan kaki pada sistem. Dalam simulasi tersebut dapat dilihat bahwa semakin padat lokasi kawasan Boulevard tersebut maka waktu untuk melakukan evakuasi pun akan semakin lama.
\end{abstract}

Kata kunci : Cellular Automata, Simulasi, Kawasan Boulevard, Evakuasi, Mitigasi Bencana.

\section{PENDAHULUAN}

Posisi Indonesia yang terletak di daerah tropis serta diapit oleh dua benua dan dua samudera menjadikan Indonesia memiliki kawasan pesisir yang sangat luas. Keunggulan ini menawarkan potensi sumber daya alam yang besar serta keuntungan ekonomis di dalamnya. Daerah pesisir didefinisikan sebagai jalur darat yang berdampingan dengan laut dengan lebar bervariasi. Dengan kondisi geografis yang dimiliki oleh Indonesia maka daerah pesisir dan pulau-pulau berpotensi besar mengalami bencana alam, seperti gempa bumi, tsunami, angin topan, dan badai.

Dalam sebuah paparan pada Forum Kajur Teknik Sipil Politeknik se-Indonesia pada tahun 2015, salah satu isu yang diangkat yakni Sulawesi Utara adalah daerah rawan gempa bumi dan berpotensi terkena dampak bencana tsunami akibat magnitude 8.1 SR, dengan potensi dihantam tsunami mencapai ketinggian lima meter. Analisa tersebut didasarkan pada data patahan karakteristik pantai, jarak dari pusat gempa dan sebagainya.[1]

Untuk itu diperlukan kewaspadaan dalam menangani hal ini. Terutama untuk daerah Boulevard yang berada di pesisir pantai dan memiliki pengunjung yang cukup padat, diperlukan penanganan khusus. Melakukan evakuasi bencana pada kawasan seperti ini diperlukan penanganan yang tepat, mengingat kondisi dan situasi pada lokasi ini yang tidak tetap. Kepadatan pengunjung dapat berubah pada jam ataupun hari tertentu. Evakuasi di siang hari tentu berbeda dengan malam hari. Untuk mengetahui penanganan evakuasi yang tepat, biasanya dilakukan drill atau uji coba evakuasi. Hal ini diperlukan partisipan yang besar serta dana yang tidak kecil pula. Untuk menekan hal itu, bisa digunakan simulasi sistem.

Kita dapat menggunakan simulasi untuk memperkiraan waktu evakuasi dengan beragam skenario bencana yang mungkin terjadi. Hal inilah yang melatar belakangi penulis untuk melakukan peneletian mengenai Pemodelan dan Simulasi Pedestrian untuk Evakuasi Bencana pada Kawasan Boulevard Manado. Diharapkan dengan model simulasi dapat dilihat beragam kemungkinan pada saat evakuasi bencana, sehingga nantinya dapat dipelajari untuk penanganan yang lebih efektif.

\section{LANDASAN TEORI}

\section{A. Pemodelan dan Simulasi}

Simulasi merupakan suatu teknik meniru operasi-operasi atau proses-proses yang terjadi dalam suatu sistem dengan bantuan perangkat komputer dan dilandasi oleh beberapa asumsi tertentu sehingga sistem tersebut bisa dipelajari secara ilmiah [6]

Dalam simulasi digunakan komputer untuk mempelajari sistem secara numerik, dimana dilakukan pengumpulan data untuk melakukan estimasi statistik untuk mendapatkan karakteristik asli dari sistem. 
Menurut Law and Kelton, Pendekatan simulasi diawali dengan pembangunan model sistem nyata[6]. Model tersebut harus dapat menunjukkan bagaimana berbagai komponen dalam sistem saling berinteraksi sehingga benar-benar menggambarkan perilaku sistem. Setelah model dibuat maka model tersebut ditransformasikan ke dalam program komputer sehingga memungkinkan untuk disimulasikan.

Law dan Kelton menjelaskan beberapa keuntungan menggunakan simulasi adalah sebagai berikut:

- Memiliki fleksibilitas yang besar dalam memodelkan suatu sistem yang kompleks, sehingga meningkatkan keabsahan dari suatu model simulasi.

- Memudahkan dalam perbandingan dengan alternatifalternatif lain.

- Kondisi dalam eksperimen yang dapat dikontrol

- Sistem dapat dipelajari dalam jangka waktu yang lama.

- Dapat mengontrol skala waktu

- Sebagian besar sistem riil dengan elemen-elemen stokastik tidak dapat dideskripsikan secara akurat dengan model matematik yang dievaluasi secara analitik. Dengan demikian simulasi seringkali merupakan satu-satunya cara.

- Sistem eksisting tidak diperlukan

\section{B. Cellular Automata}

Cellular Automata pertama kali diperkenalkan oleh John Von Neuman dan Stain Slaw Marchin Ulam dengan nama awal cellular space pada tahun 1948, sebagai idealisasi sistem biologi. Ulam dan von Neuman menggunakan Cellular Automata sebagai dasar untuk menyelediki fenomena yang bersifat kompleks.

Wolfram dalam Computation Theory of Celullar Autamata, mendefenisikan $C A$ sebagai sekumpulan sel yang memiliki status tertentu yang disusun dalam sebuah array, yang berevolusi sebanyak jumlah iterasi yang terbatas, sesuai dengan aturan tertentu dan keadaan sel di sekitarnya. Sel akan berevolusi tiap satuan waktu sesuai dengan aturan perubahan (update rule) dan keadaan sel tetangga.[8]

\section{Simulation Life Cycle}

Simulation Lifecycle merupakan siklus pengembangan dari sebuah sistem simulasi. Tahap-tahap yang terdapat dalam Simulation sebagaimana yang ditulis oleh Roger McHoney dalam Understanding Computer Simulation, antara lain sebagai berikut[7] :

- Intelligence Phase, Merupakan tahap pendahuluan tentang pemahaman suatu masalah. melibatkan pemahaman lingkungan dan menentukan masalah yang harus dipecahkan.
- Managerial Phase, Langkah ini memerlukan interaksi dengan manajemen dan staf non-teknis lainnya untuk memperoleh sumber daya yang diperlukan dan mendukung pembentukan tim proyek simulasi. Tahap ini memfasilitasi keterlibatan organisasi dalam proyek simulasi.

- Developmental Phase, Tahap ini merupakana tahap Pembuatan Simulasi.

- Quality Assurance Phase, Tahap ini merupakan tahap yang berlangsung bersamaan dengan tahap development. Tahap ini dilakukan untuk memastikan kualitas dari sebuah sistem simulasi yang dikembangkan. Langkah utama yang dilakukan pada tahap ini adalah langkah uji validasi.

- Implementation Phase, Tahap ini merupakan tahap menginisialisasi parameter kunci dalam model dan menjalankan sistem untuk membuat kesimpulan tentang perilaku sistem yang diteliti.

- Operations, Maintenance, and Archival Phase, Dalam tahap ini, sistem dan dokumentasinya disimpan. Kemudian sistem dikonversi ke model end-user untuk dioperasikan. Selain itu dalam tahap ini juga dilakukan rencana pemeliharaan (maintenance).

\section{D.Microsoft Visual Basic .NET}

Microsoft Visual Basic .NET adalah sebuah alat untuk mengembangkan dan membangun aplikasi yang bergerak di atas sistem .NET Framework, dengan menggunakan bahasa BASIC. Bahasa Visual Basic .NET sendiri menganut paradigma bahasa pemrograman berorientasi objek yang dapat dilihat sebagai evolusi dari Microsoft Visual Basic versi sebelumnya yang diimplementasikan di atas .NET Framework.

Microsoft .NET Framework atau lebih dikenal dengan singkatan dot net merupakan sebuah perangkat lunak kerangka kerja yang berjalan utamanya pada sistem operasi Microsoft Windows. Kerangka kerja ini menyediakan sejumlah besar pustaka pemrograman komputer dan mendukung beberapa bahasa pemrograman serta interoperabilitas yang baik sehingga memungkinkan bahasabahasa tersebut berfungsi satu dengan lain dalam pengembangan sistem.Kerangka kerja ini menyediakan sejumlah besar pustaka pemrograman komputer dan mendukung beberapa bahasa pemrograman serta interoperabilitas yang baik sehingga memungkinkan bahasabahasa tersebut berfungsi satu dengan lain dalam pengembangan sistem. 


\section{E. Ruang Terbuka Sebagai Ruang Evakuasi Bencana}

Ruang terbuka publik pada dasarnya merupakan suatu wadah yang dapat menampung aktivitas/kegiatan tertentu dari masyarakatnya, baik secara individu maupun kelompok, yang meliputi jalan, pedestrian, taman, plaza, pemakaman di sekitar lapangan terbang dan lapangan olahraga.[2]

Fungsi utama ruang terbuka publik terbagi menjadi dua, pertama sebagai fungsi sosial dimana sebagai tempat bermain dan berolahraga, tempat komunikasi sosial, tempat peralihan dan tempat menunggu, tempat untuk mendapatkan udara segar dengan lingkungan, sarana penghubung antara suatu tempat dengan tempat lain, pembatas atau jarak diantara massa bangunan, sarana penelitian dan pendidikan serta penyuluhan bagi masyarakat untuk membentuk kesadaran sosial, sarana untuk menciptakan kebersihan, kesehatan, keserasian dan keindahan lingkungan sedangkan fungsi yang kedua adalah sebagai fungsi ekologis yaitu sebagai penyegar udara, mempengaruhi dan memperbaiki iklim mikro, menyerap air hujan, pengendali banjir dan pengatur tata air, memeliharaekosistem tertentu dan perlindungan plasma nutfah serta sebagai pelembut arsitektur bangunan.[4]

\section{F. Kebijakan Mitigasi Bencana di Wilayah Pesisir}

Dalam konteks pengendalian dan pengelolaan sumberdaya pesisir dan kelautan, terdapat beberapa tantangan dan permasalahan seperti karakteristik sumberdaya, keterbatasan pengalaman, kurangnya data dan informasi, terbatasnya pendanaan dan lain sebagainya. Selain itu pelaksanaan desentralisasi pengelolaan sumberdaya alam pada saat ini telah memunculkan adanya peralihan beberapa kewenangan pusat ke daerah. Peralihan kewenangan tersebut menuntut tanggung jawab yang semakin besar dari semua pihak terhadap pengelolaan sumberdaya pesisir dan laut.[3]

\section{METODOLOGI PENELITIAN}

\section{A. Kerangka Kerja \\ Berikut merupakan kerangka kerja yang dibuat.}

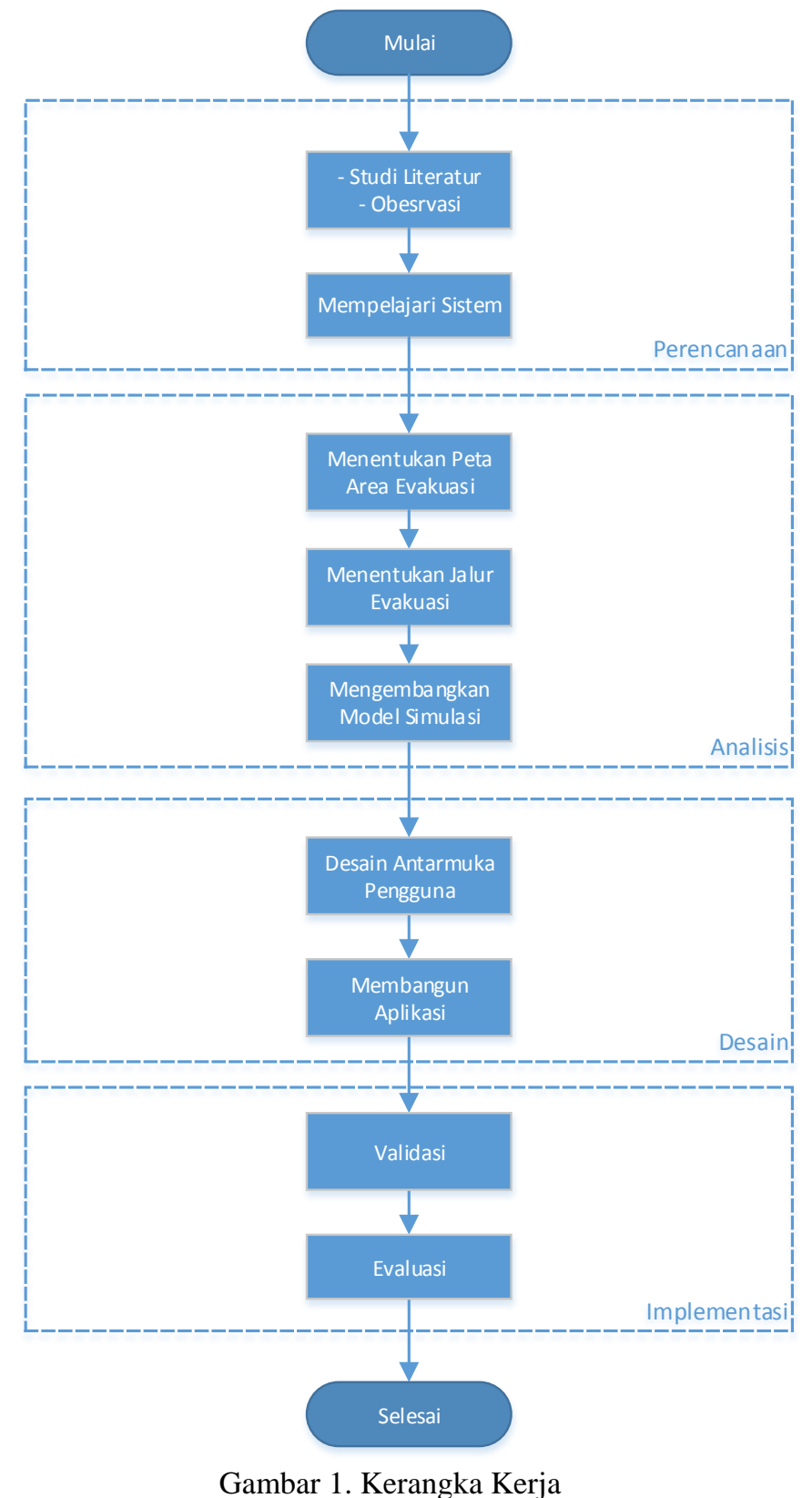

B. Analisa Data

Seperti yang dijelaskan pada batasan masalah, lokasi evakuasi yang akan dibuatkan simulasi yakni pada kawasan boulevard kota Manado. Evakuasi difokuskan pada area dari sekitaran Manado Trade Center (MTC) sampai pada area Megamall Manado. Seperti yang terlihat pada gambar 2 berikut: 


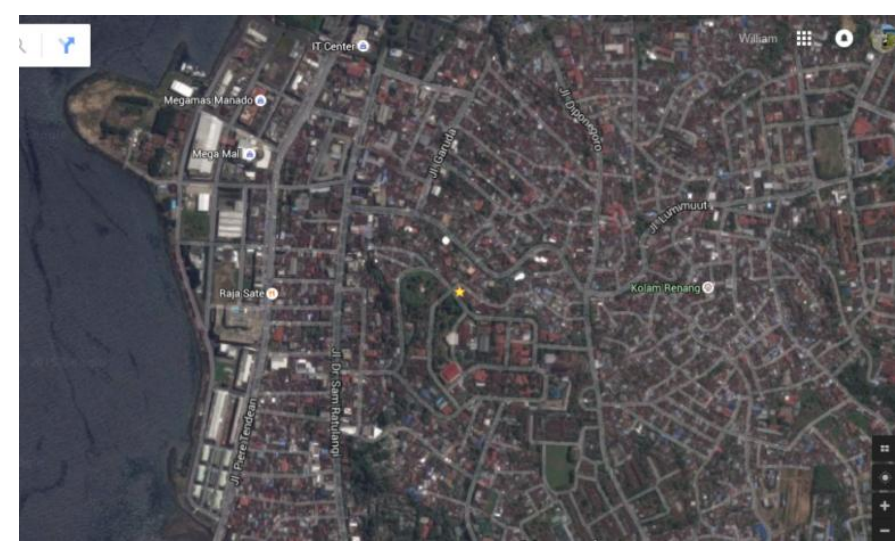

Gambar 2 Peta Lokasi Evakuasi

Selanjutnya dengan menggunakann peta resiko tsunami kota Manado pada gambar 3, ditentukan lokasi yang menjadi titik kumpul evakuasi. Lokasi titik kumpul harus memenuhi beberapa kriteria, seperti luas area dan ketinggian yang dianggap aman.

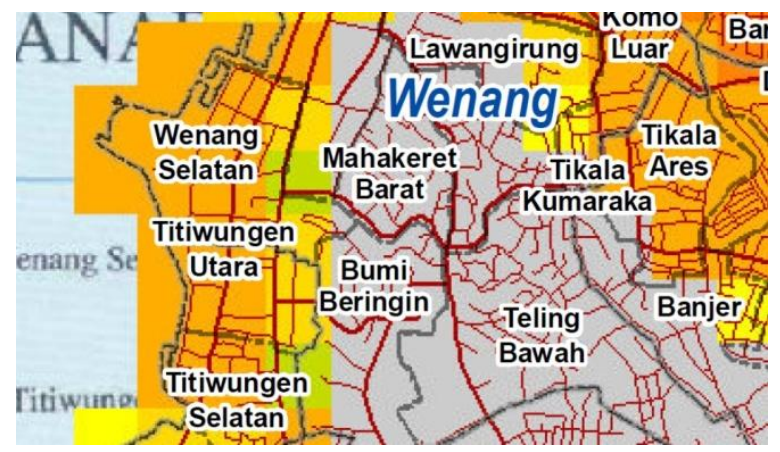

Gambar 3 Peta Resiko Tsunami Kota Manado

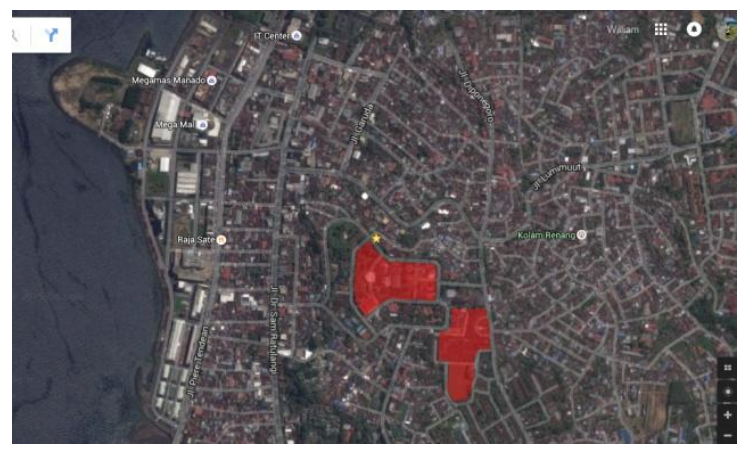

Gambar 4 Area Titik Kumpul

Selanjutnya ditentukan jalur evakuasi seperti gambar berikut:

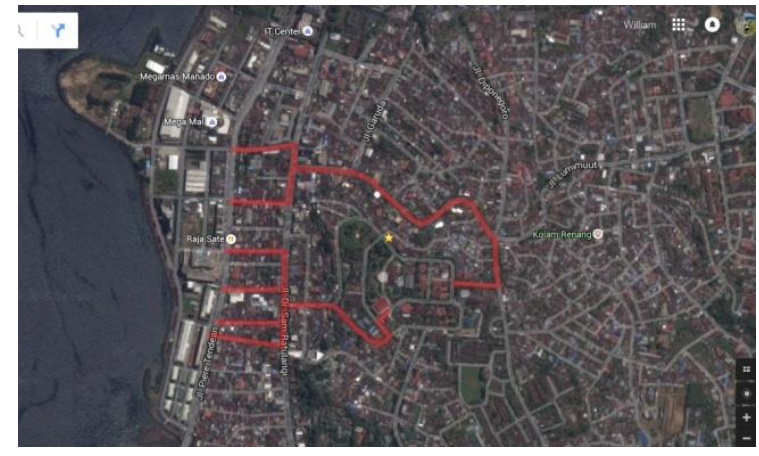

Gambar 5 Jalur Evakuasi

Jalur evakuasi di atas merupakan asumsi yang diambil berdasarkan pada luas ruas jalan dan jarak yang dianggap terbaik. Untuk area sekitaran MTC diasumsikan pejalan kaki dapat memasuki lorong-lorong untuk akses dari Jl. Boulevard ke Jl. Sam Ratulangi, kemudian melewati Jl. Ch. Taulu (Sri Solo) untuk menuju ke Area Perumahan Gubernuran di Bumi Beringin. Sementara itu, untuk area Mega Mall, dapat menuju ke Jl. Sam Ratulangi kemudian mengikuti Jl. Toar untuk menuju ke Bumi Beringin ataupun menuju ke Teling.

\section{Perancangan Sistem}

Sistem simulasi ini secara garis besar bisa dilihat pada gambar 6 berikut. User hanya perlu melakukan input jumlah pedestrian kemudian simulasi akan dimulai.

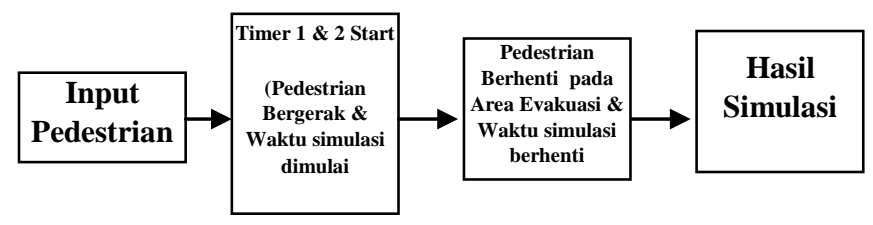

Gambar 6 Alur Kerja Pada Sistem

Sebelum simulasi dimulai, perlu diinput jumlah pedestrian dalam simulasi. Pemanggilan pedestrian ini dengan menggunakan array. 1 objek mewakili 10 pedestrian, sehingga jumlah objek $=$ input $/ 10$. Objek-objek pedestrian tersebut kemudian akan dimunculkan secara acak pada area berikut. 


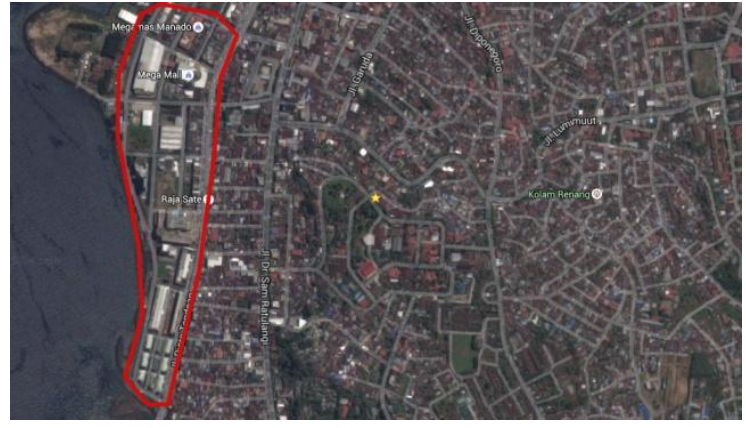

Gambar 7 Area Muncul Pedestrian pada Sistem

Kemudian Objek-objek tersebut akan bergerak kea rah tujuannya masing-masing sesuai dengan aturan yang berlaku.

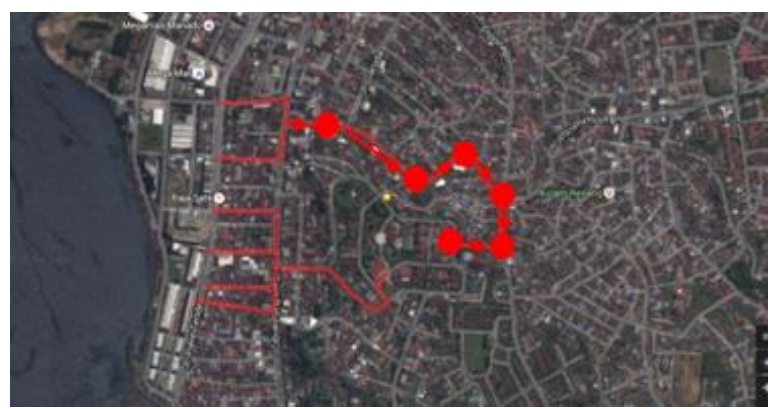

Gambar 8 Jalur Pedestrian di Area A

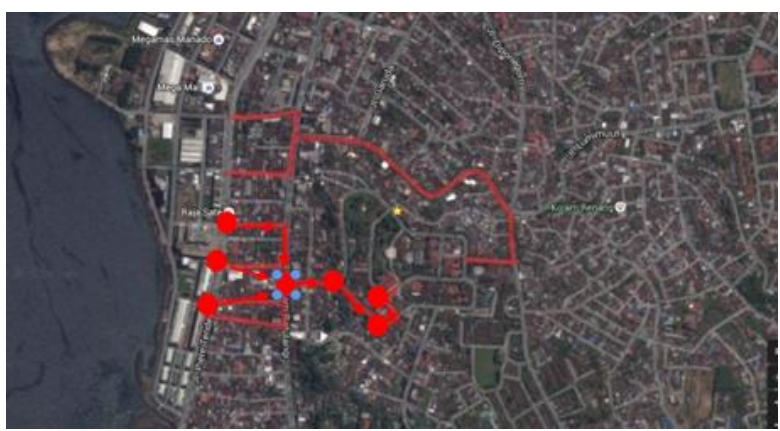

Gambar 9 Jalur Pedestrian di Area B

\section{IV.HASIL DAN PEMBAHASAN}

A. Tampilan Aplikasi

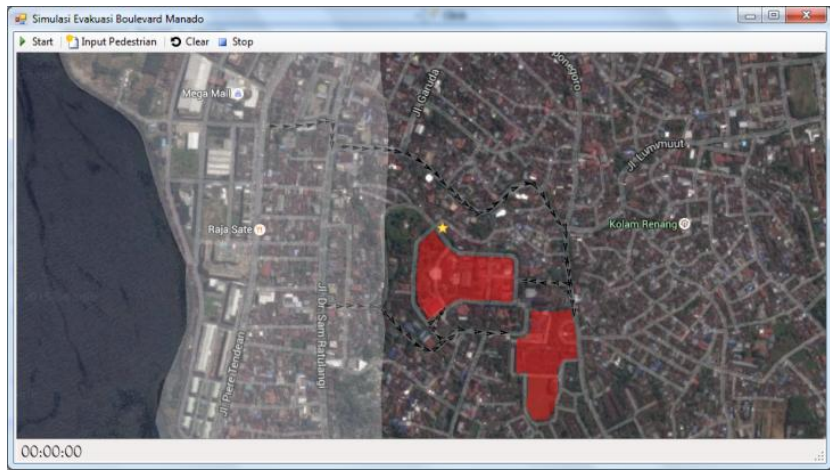

Gambar 10 Tampilan Utama Sistem Simulasi

Gambar 10 di atas merupakan tampilan utama setelah aplikasi dibuka. Menampilkan peta kota Manado untuk lokasi evakuasi bencana di sekitaran Boulevard Manado.

Pada Peta, area arsiran putih merupakan area dengan resiko tsunami. Sedangkan area merah merupakan area yang dituju pejalan kaki dalam evakuasi bencana. Titik hitam merupakan jalur yang diambil pejalan kaki untuk menuju ke titik evakuasi.

Bagian atas dari aplikasi terdapat 4 tombol dengan fugsi masing-masing. 4 tombol tersebut yaitu Start, Input Pedestrian, Clear dan Stop. Sedangkan pada bagian bawah terdapat waktu atau timer yang menghitung lamanya waktu simulasi.

\section{Input Pedestrian}

Tombol input pedestrian digunakan untuk menginput jumlah pejalan kaki yang akan disimulasikan di dalam sistem. Sebelum simulasi dimulai, user diharuskan untuk menginput jumlah pedestrian yang diinginkan.

Akan muncul input-box untuk melakukan inputan jumlah pedestrian. Inputan untuk jumlah pedestrian harus berupa angka atau integer. Kemudian shape yang mewakili 1 grup (10 orang) pedestrian akan muncul secara random atau acak pada area boulevard.

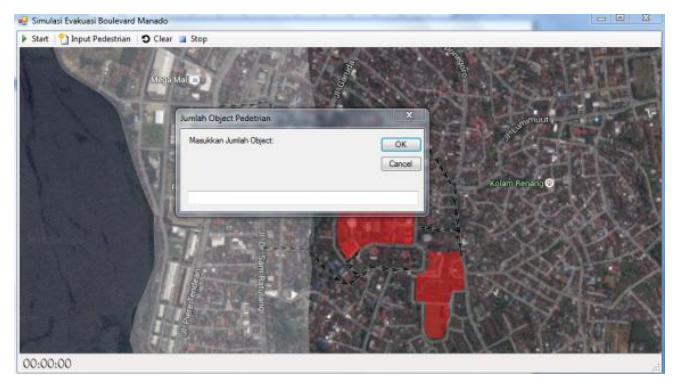

Gambar 11 Input-Box yang muncul untuk input pedestrian 


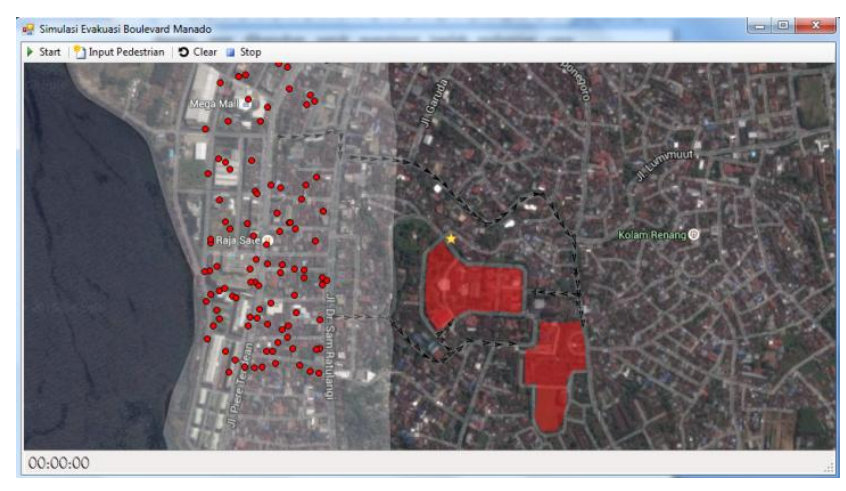

Gambar 12 Shape yang mewakili pedestrian muncul secara acak

Setelah tombol stop di-klik, hasil simulasi akan muncul dalam form seperti pada gambar berikut, berisi jumlah pedestrian yang tadi diiput serta lama waktu simulasi pada sistem.

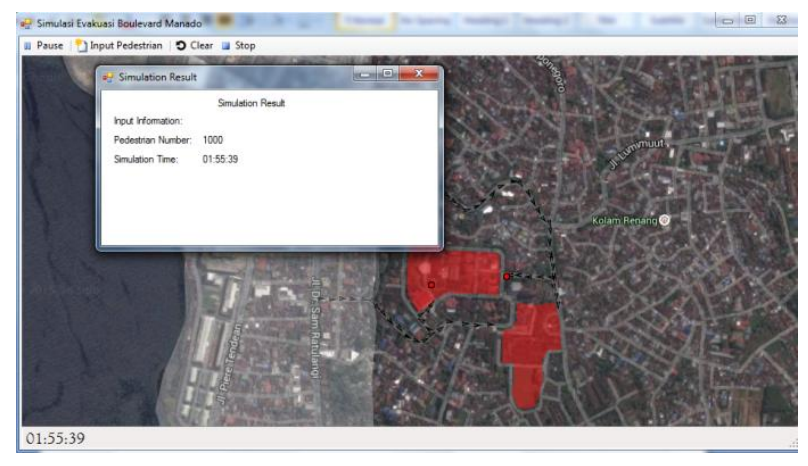

Gambar 13 Hasil Simulasi

\section{B. Pengujian Sistem}

Sistem akan diuji dengan menggunakan inputan dengan jumlah objek pejalan kaki yang berbeda-beda. Kemudian akan dilihat lama waktu yang ditunjukan oleh sistem untuk memperlihatkan Simulasi tersebut.

Tabel berikut akan menunjukan hasil pengujian dengan jumlah inputan pedestrian yang berbeda-beda

Tabel 1 Pengujian Inputan Pedestrian

\begin{tabular}{|c|c|c|}
\hline No & Jumlah Inputan & Waktu \\
\hline 1 & 10 & $00: 36: 94$ \\
\hline 2 & 50 & $00: 46: 95$ \\
\hline 3 & 100 & $00: 47: 91$ \\
\hline
\end{tabular}

\begin{tabular}{|c|c|c|}
\hline 4 & 300 & $00: 50: 66$ \\
\hline 5 & 500 & $00: 52: 79$ \\
\hline 6 & 1000 & $00: 57: 58$ \\
\hline 7 & 5000 & $01: 11: 56$ \\
\hline
\end{tabular}

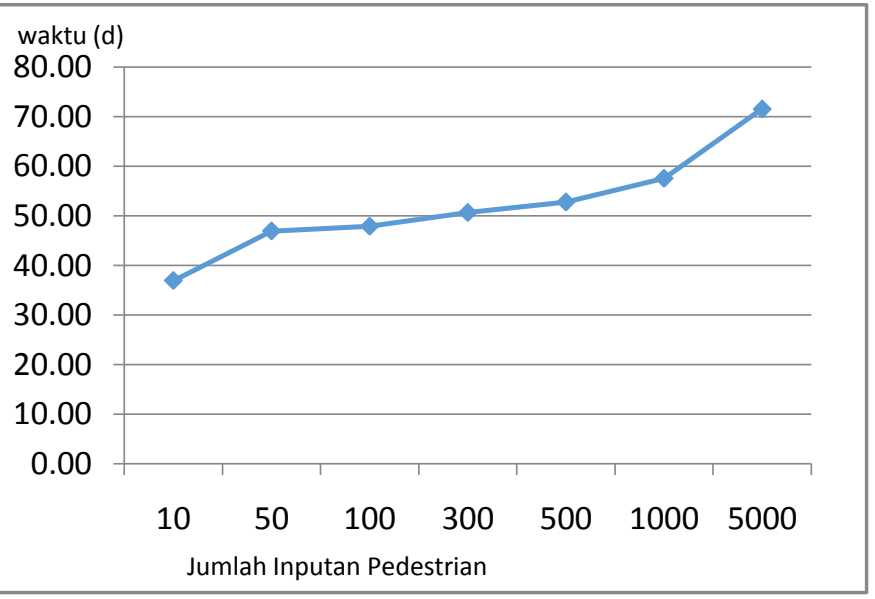

Gambar 14 Grafik Pengujian Jumlah Inputan

Dari table 1 bisa dilihat bahwa pada simulasi, semakin tinggi jumlah inputan atau semakin banyak pedestrian, maka waktu evakuasi akan semakin lama. Peningkatan waktu meningkat tinggi pada penginputan 5000 pedestrian, terjadi perbedaan sebesar 15 detik pada sistem dengan inputan 1000 .

\section{PENUTUP}

\section{A. Kesimpulan}

Berdasarkan hasil pembahasan Pemodelan dan Simulasi Pedestrian Untuk Evakuasi Bencana pada Kawasan Boulevard Manado Menggunakan Model Cellular Automata, maka dapat disimpulkan sebagai berikut:

1. Telah dibangun Model Simulasi dengan menggunakan Model Cellular Automata memanfaatkan ovalshape dan peta kota manado sebagai sel dan grid. Dengan model cellular Automata kita dapat

2. Jumlah pedestrian dalam simulasi ini dapat ditentukan antara 0 sampai 9000 pedestrian. Semakin banyak pedestrian yang diinput, maka waktu untuk melakukan simulasi pun akan semakin lama.

3. Dengan menggunakan model simulasi ini dapat dipelajari penanganan yang tepat dalam melakukan 
evakuasi khususnya pada kawasan Boulevard kota Manado.

\section{B. Saran}

1. Untuk pengembangan selanjutnya dapat ditambah pemilihan jalur yang lebih efektif pada simulasi.

2. Pada program sebaiknya diperbaiki pergerakan dan perpindahan sel atau titik untuk diperolehnya waktu simulasi yang lebih real.

3. Dalam pengembangan simulasi selanjutnya dapat ditambah probabilitas-probabilitas gangguan simulasi laiinya.

\section{DAFTAR PUSTAKA}

[1] Alkhair, J Hafidz. 2012. Jurusan Teknik Sipil Universitas Riau."Simulasi Evakuasi Berbasiss SIG Untuk Analisis Tingkat KerentananPenduduk Kota Padang Terhadap Bahaya Tsunami".

[2] Carr S. 1992. Public Space. Cambridge University Press. United States

[3] Departemen Kelautan dan Perikanan. 2005. "Mitigasi Bencana Alam di Wilayah Pesisir". Jakarta

[4] Hakim R, Utomo H. 2003. Komponen Perancangan Arsitektur Lanskap Prinsip Unsur dan Aplikasi Desain. Bumi Aksara. Jakarta

[5] Harjo, B. 1997. Arsitektur Pembangunan dan Konservasi. Djambatan. Jakarta

[6] Law A, Kelton D. 1991. Simulation Modelling and Analysis. McGraw-Hill College. United States

[7] McHoney R. 2009. Understanding Computer Simulation. Ventus Publishing. United States

[8] Wolfram S. 1984. Computation Theory of Cellular Automata. Comm. Math. Phys. United States.

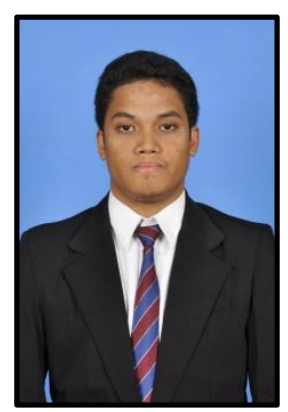

Sekilas dari penulis dengan nama lengkap William Dave Wenno, lahir di kota Ambon, Provinsi Maluku. Anak ke-2 dari 3 bersaudara. Dengan pendidikan pertamadi Sekolah Dasar SD Negeri 2 Halong. Kemudian Melanjutkan ke Sekolah Menengah Pertama SMP Negeri 9 Ambon. Kemudian melanjutkan ke Sekolah Menengah Atas SMA Negeri 1 Ambon. Setelah lulus tahun 2011 melanjutkan ke Perguruan Tinggi di Universitas Sam Ratulangi Manado dengan mengambil Jurusan Teknik Informatika. Pada tahun 2015 bulan Juni, penulis membuat Skripsi demi memenuhi syarat Sarjana (S1) dengan penelitian berjudul Pemodelan dan Simulasi Pedestrian Untuk Evakuasi Bencana pada Kawasan Boulevard Manado Menggunakan Model Cellular Automata yang dibimbing oleh dua dosen pembimbing yaitu Dr. Eng. Steven R. Sentinuwo, ST., MTI dan Alwin M. Sambul, ST., M.Eng., Ph.D sehingga pada tanggal 29 September 2016 penulis resmi lulus di Teknik Informatika Universitas Sam Ratulangi Manado dan menyandang gelar Sarjana Komputer dengan predikat Sangat Memuaskan. 